\title{
A liminalitás terei és idői az európai posztszovjet térben az orosz és szovjet expanziós törekvések tükrében
}

\section{Spaces and times of liminality in Russian and Soviet expansion endeavours}

\author{
KŐSZEGI MARGIT, BERKI MÁRTON, BARTA GÉZA
}

KŐSZEGI Margit: tudományos munkatárs, Eötvös Loránd Tudományegyetem, Természettudományi Kar, Földrajz- és Földtudományi Intézet, Regionális Tudományi Tanszék; 1117 Budapest, Pázmány Péter sétány 1/C.; koszegi.margit.email@gmail.com; https:// orcid.org/0000-0002-2494-8328

BERKI Márton: egyetemi adjunktus, Eötvös Loránd Tudományegyetem, Természettudományi Kar, Földrajz- és Földtudományi Intézet, Társadalom- és Gazdaságföldrajzi Tanszék; 1117 Budapest, Pázmány Péter sétány 1/C.; berkimarton@yahoo.com; https://orcid.org/0000-0002-0727-1212

BARTA Géza: PhD-hallgató, Eötvös Loránd Tudományegyetem, Természettudományi Kar, Földrajz- és Földtudományi Intézet, Regionális Tudományi Tanszék; 1117 Budapest, Pázmány Péter sétány 1/C.; gezabarta@gmail.com; https://orcid.org/0000-0001-6353-4788

KULCSSZAVAK: liminalitás; expanzió; hatalom; identitás; struktúra

ABSZTRAKT: A tanulmány az európai posztszovjet térségben érvényesülő orosz expanziós törekvések hatásait a liminalitás koncepciójára építve értelmezi. Az Arnold van Gennep által megalkotott, majd Victor Turner által kiszélesített fogalom olyan átmeneteket (határhelyzeti állapotokat) jelöl, amikor a társadalmi hierarchiák ideiglenesen feloldódnak, egyes tradíciók folytonossága megkérdőjeleződik és az addig biztosnak hitt struktúrák kétségessé válnak. Ezekben a liminális időszakokban a korábbi rend felbomlása olyan bizonytalan, s egyúttal fluid, képlékeny helyzeteket eredményez, amelyek lehetővé teszik egy új állapot megszilárdulását. Tanulmányunkban e koncepció segítségével ragadjuk meg azokat az átmenetként értelmezhető időszakokat, amelyek átfogó változást idéztek elő az orosz expanziós törekvések által érintett térségekben. Az orosz expanzió hatásainak vizsgálatában négy liminális időszakot állítunk a középpontba, amelyeket a meghatározó területi irányok mentén élő, érintett népek példáin keresztül mutatunk be. Elsőként a 18. századi, Fekete-tenger felé érvényesülő orosz expanzió által a krími tatár közösségek életében előidézett liminalitást vizsgáljuk. Ezt követően a cári birodalmat felváltó, a szovjet szocialista berendezkedés hatására jelentkező liminalitást mutatjuk be a Kaukázus térségében, a csecsenek példáján. A 20. század végén bekövetkező rendszerváltás lehetőséget adott a szovjet időszak liminalitásának megszűnésére, amit a balti államokban bekövetkező változások kapcsán vizsgálunk. Végezetül az ukrán polgárháborús helyzet hátterének feltárásával rávilágítunk az ukrán társadalomban külső hatásra jelentkező elhúzódó liminalitásra, valamint annak geopolitikai mozzanataira.

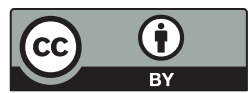


Margit KÖSZEGI: research fellow, Department of Regional Science, Institute of Geography and Earth Sciences, Faculty of Science, Eötvös Loránd University; Pázmány Péter sétány 1/C., H-1117 Budapest, Hungary; koszegi.margit.email@gmail.com; https://orcid.org/0000-0002-2494-8328

Márton BERKI: senior lecturer, Department of Social and Economic Geography, Institute of Geography and Earth Sciences, Faculty of Science, Eötvös Loránd University; Pázmány Péter sétány 1/C., H-1117 Budapest, Hungary; berkimarton@yahoo.com; https://orcid.org/0000-0002-0727-1212

Géza BARTA: PhD student, Department of Regional Science, Institute of Geography and Earth Sciences, Faculty of Science, Eötvös Loránd University; Pázmány Péter sétány 1/C., H-1117 Budapest, Hungary; gezabarta@gmail.com; https://orcid.org/0000-0001-6353-4788

KEYWORDS: liminality; expansion; power; identity; structure

ABSTRACT: Based on the concept of liminality, the paper focuses on the effects of Russian expansion endeavours in various areas of the European post-Soviet realm. The notion of liminality, originally elaborated by Dutch-German-French ethnographer and folklorist Arnold van Gennep and subsequently expanded by British cultural anthropologist Victor Turner, denotes transitions ('threshold' situations) during which social hierarchies temporarily dissolve, the continuity of prior traditions are questioned, and formerly fix structures become uncertain. During these liminal periods, the dissolution of order evokes ambiguous, fluid and malleable situations that enable the establishment of another fix structure. The theoretical framework of liminality can be applied in the case of various temporalities (spanning from immediate moments through periods to longer epochs), at any geographical scales (ranging from concrete localities through larger areas or zones to entire countries or macro-regions), as well as for any subjects including individuals, different social groups, and in the case of entire societies - within the confines of this paper, we provide examples of the latter. In spite of the exceptional versatility and flexibility of the notion, however, it has not been substantially exploited in the field of human geography to date.

With the help of this underlying concept, we examine liminal periods which triggered allencompassing changes in the areas affected by Russian expansion endeavours. Concerning the impacts of Russian expansion, we identify four main liminal time periods that are discussed on the example of the affected nations and their respective territories. 1. First, we provide a concise overview of the liminality experienced by Crimean Tatar communities as a result of the 18th century Russian expansion towards the direction of the Black Sea. 2. After that, on the example of Chechens, we describe liminality in the Caucasian region that was generated by the Soviet socialist state, the successor of the Russian Tsarist Empire. 3. Following that, the politicoeconomic transition of the late-20th century created an opportunity to leave the constraints of the Soviet era behind, which is discussed in the context of the changes taking place in the Baltic states. 4. Lastly, by exploring the background of the current situation in Ukraine, reflections are made on the external factors of prolonged liminality in Ukrainian society, as well as on its geopolitical connotations.

\section{Bevezetés}

Egy 2018 tavaszán készült felmérés szerint az orosz közvélemény 70\%-a a Krím annexióját Oroszország számára előnyösnek gondolja. ${ }^{1}$ Az erős tradíciókra támaszkodó orosz geopolitikai kultúra közpolitikai jelenlétét az olyan felmérések elkészítése és eredményei is igazolják, amelyek az ország viszonylagos és szimbolikus szerepét, fontos nemzetközi kapcsolatait és a világpolitikai térben való elhelyezkedését firtatják (O’Loughlin, Ó Tuathail, Kolossov 2006). Oroszország 
határainak (újra)definiálása, megerősítése, a környező országokhoz és a nagyhatalmakhoz viszonyuló külpolitika meg- és újrateremtése mélyen gyökerezik az orosz politikai kultúrában (Kerr 1995). Ezek a gyökerek pedig elvezetnek az államiság kialakulásához, Oroszország expanziós törekvéseihez, a folyamatos növekedéshez, miközben a hatalmi központ egyre távolabb kerül az ország határaitól. Az új területeken berendezkedő orosz hatalom számtalan problémával szembesül, a központtal való azonosulást a helyi szokások és ellenállások vagy szeparatista törekvések gátolják.

Tanulmányunkban az orosz állam peremterületein, a mindenkori hatalmi központ felé irányuló centripetális erők és az azok ellen ható, adott időszakban periferiális helyzetű területek által keltett centrifugális erők árapályzónájában elhelyezkedő térségekre fókuszálunk. Vizsgálatunkban tehát a posztszovjet kifejezés a térre, az egykori Szovjetunió területén élő bizonyos közösségekre vonatkozik (vö. Tuvikene 2016). E régiók esetében olyan időpontokra összpontosítunk, amikor az orosz expanzió következtében a régi struktúrák már fellazulnak és értelmüket vesztik, az újak azonban még nem alakulnak ki. Nem az orosz expanzió által generált folyamatos változást, az olykor tudatosan generált átmenetiséget (Pain 2016) vizsgáljuk, hanem a konkrét időszakokhoz köthető, egyértelműen jelentkező váltásokat tárjuk fel. Bizonyos területeken ez a folyamat rövidebb ideig tart, máshol azonban elhúzódik. Az ehhez hasonló helyzetek megragadására kínál lehetőséget az Arnold van Gennep és Victor Turner által kidolgozott liminalitás koncepciója, melynek alkalmazásával egységes keretbe foglalhatjuk a térben és időben egyébként elkülönülő eseményeket. Vizsgálataink a perifériákon élő közösségekre koncentrálnak, kiemelve az események hatására újrakonstruált identitásnarratívákat. Az orosz társadalom életében megjelenő hasonló vált(oz)ások nem az expanziós törekvések eredményeként jelentkeztek, tanulmányunknak ezért nem célja ezek bemutatása. Mivel a posztszovjet tér peremén élő közösségek életében megjelenő váltásokra fókuszálunk, így az expanzió jellegének és jellemzőinek változásait sem tárgyaljuk részletesen.

Nem kívánjuk egységes rendszerbe foglalni a liminalitással kapcsolatba hozható orosz periferiális területeket: az általunk választott négy térséghez köthető események eltérő történelmi korszakokban, különböző társadalmi és kulturális közegben zajlanak. A heterogén régiók közötti kapcsolatot az orosz expanzió adja (a négy térség ugyanis az európai terjeszkedés négy különböző irányát reprezentálja): választott példáink az orosz expanzió területenként és korszakonként változó cél- és eszközrendszere által előidézett liminalitást szemléltetik. Az egyes időszakokban, konkrét területen élő társadalomban bemutatott liminalitás nem jelent kizárólagosságot sem térben, sem időben: az állapot jelentkezhet ismételten máskor (akár ismét az expanziós politika hatására), illetve történhet párhuzamosan, a különböző kiemelt területek felé irányuló terjeszkedés révén is. Értelmezési keretünk az egész társadalomra mint elképzelt közösségre vonatkozik (Anderson 2006), amivel nem vonjuk kétségbe a belső törésvonalak, a társadalmi hibriditás létét, valamint egyéb, a kö- 
zösségeket befolyásoló tényezők markáns szerepét. További célunk, hogy - a társadalomföldrajz és a kulturális antropológia interdiszciplináris lehetőségeit kihasználva - a földrajzi terekhez köthető társadalmi jelenségeket a magyar és nemzetközi földrajzi diszciplínában ez idáig ritkán alkalmazott elméleti keret segítségével értelmezzük.

\section{A liminalitás koncepciója}

A liminalitás kifejezés a latin „līmen” (= küszöb) szóból származik, megalkotása a holland-német-francia etnográfus és folklorista Arnold van Gennep (1909) nevéhez füződik. A koncepciót kis közösségek rítusainak megértésére dolgozta ki, amelyeknek három szakaszát különböztette meg. Az első a preliminális szakasz (az elkülönülés rítusai), melynek során a beavatandó személy vagy csoport a korábbi gyakorlataival, rutinjaival szakítva valamit végérvényesen hátrahagy. Ezt követi a liminális szakasz (az átmenet rítusai), melynek során - egyfajta „küszöböt” átlépve - bizonytalanná válik a beavatandó(k) státusza; itt lényeges egyrészt az, hogy a rítus szigorú előírások szerint történjen, ahol mindenki tudja, hogy mit és hogyan kell tennie, másrészt pedig az, hogy a rítus mindig egy „,szertartásmester" felügyelete mellett menjen végbe. Végül a harmadik a posztliminális szakasz (az [újra] egyesülés rítusai), melynek során a már beavatott személy vagy csoport „visszatér" a társadalomba, ám immár új (más) identitással rendelkezik.

Mivel van Gennep sohasem tudott fontos pozíciót betölteni a korabeli tudományos mezőben (Thomassen 2009, 13.), így a rítusokkal kapcsolatos gondolatai is hosszú időre feledésbe merültek. Azok újrafelfedezésére csupán fél évszázaddal később, a brit kulturális antropológus Victor Turner $(1967,1969)$ munkásságának köszönhetően került sor, aki a fenti hármas felosztásból főként a középsőre, a liminális szakaszra helyezte a hangsúlyt, másrészt van Gennep eredeti elképzelését sok szempontból tovább is gondolta. A legtipikusabb rítusnak Turner (1967) a felnőtté válási beavatási szertartásokat tartotta: ezek első szakaszában a gyermek elszakad a családjától, hátrahagyja a gyermeklétet (elkülönülés). A második szakaszban a gyermekkor és a felnőttkor között levő beavatandónak valamilyen próbát kell kiállnia annak bizonyítására, hogy készen áll a felnőtt létre (átmenet). Végül, amennyiben ez sikerrel jár, a társadalom új - immár felnőtt - tagjaként ünneplik a beavatott újjászületését ([újra]egyesülés). A középső szakasz eredményeként tehát Turner szerint megváltozik az abban résztvevő(k) társadalmi státusza: az elkülönülés során a beavatandó kiszakad a társadalmi struktúra egyik fix kategóriájából, így a státusza liminálissá válik. Ebben a helyzetben ideiglenesen az addig megszokott környezetén (és a teljes társadalmi renden) kívülre kerül, az identitása bizonytalanná válik. Mivel azonban a liminális időszakok nemcsak destruktívak, hanem konstruktívak is (Thomassen 2006), az ezek során szerzett tapasztalatok egyúttal fel is készítik a 
beavatandót arra, hogy olyan új társadalmi szerepet töltsön be, amely az (újra)egyesülés rítusa során válik mások számára is láthatóvá, nyilvánossá.

Terepi munkáját Turner többnyire afrikai törzsi közösségekben végezte, azonban számos alkalommal rámutatott a törzsi és nem törzsi társadalmak közötti hasonlóságokra, s ezáltal a liminalitás koncepciója fokozatosan eltávolodott az eredeti szűkebb - kis létszámú csoportok rítusainak megértésére irányuló - értelmezéstől. ${ }^{2}$ Miután Turner munkássága nyomán széles körben ismertté vált a fogalom, egyre sokrétúbb módon kezdték el alkalmazni, azaz már nem csupán rítusok, hanem kulturális, politikai, gazdasági változások megértésére is használták (lásd Thomassen 2009 áttekintésében, továbbá a legutóbbi átfogó munkák közül Horvath, Thomassen, Wydra 2015 és Roberts 2018 kötetében). Ebben a tágabb értelmezésben a liminalitás olyan átmeneteket (határhelyzeti állapotokat) jelöl, amikor a társadalmi hierarchiák ideiglenesen feloldódnak, egyes hagyományok folytonossága megkérdőjeleződik és az addig biztosnak hitt struktúrák kétségessé válnak (1. ábra). Turner (1969) szerint a liminalitás legfontosabb jellemvonása a bizonytalanság, ugyanis a liminális entitások (egyének, csoportok, társadalmak) „nincsenek se itt, se ott; a törvények, szokások, konvenciók és szertartások által kijelölt pozíciók közti átmeneti állapotban vannak" (95.). Ezt a köztes állapotot ugyanakkor egyúttal úgy is értékeli, mint „a lehetőségek birodalmát, amelyből merőben új gondolatok és kapcsolatok alakulhatnak ki” (97.). Látható tehát, hogy a liminális időszakokban a korábbi rend felbomlása olyan fluid, képlékeny helyzeteket eredményez, amelyek lehetővé teszik egy új állapot megszilárdulását (Szakolczai 2009, 141.).

Lényeges kiemelni, hogy e tágabb értelmezésben a liminalitás koncepciója a legkülönbözőbb időtávok és liminális entitások esetében alkalmazható (1. táblázat). Az időbeli dimenzió esetében liminálisnak tekinthető egy adott pillanat (hirtelen esemény), egy időszak (hetek, hónapok vagy akár néhány év), de akár hosszabb korszakok (évtizedek, generációk, esetleg évszázadok³) is. Ehhez hasonló módon, a liminalitás állapotában lehetnek egyének, kisebb-nagyobb csoportok (korcsoportok, törzsi közösségek, falvak, városi szubkultúrák) vagy akár egész társadalmak is. Thomassen (2009, 17-18.) szerint e két tényezőn

1. ábra: A liminalitás koncepciója van Gennep és Turner értelmezésében The concept of liminality according to van Gennep and Turner

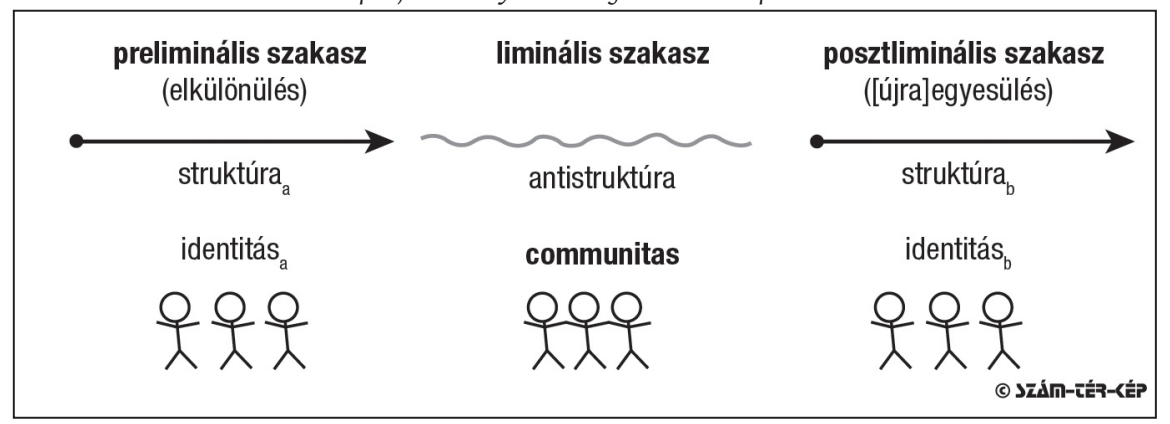


1. táblázat: A liminalitás különböző típusainak példái, az időtartamuk ( $\downarrow)$ és a résztvevők száma $(\rightarrow)$ szerint Examples of the types of liminality by their duration $(\downarrow)$ and the number of participants $(\rightarrow)$

\begin{tabular}{|c|c|c|c|}
\hline & Egyén & Csoport & Társadalom \\
\hline Pillanat & $\begin{array}{l}\text { Az egyén életét befolyásoló } \\
\text { hirtelen esemény (baleset, } \\
\text { házasságkötés, válás); meg- } \\
\text { keresztel(ked)és; szüzesség } \\
\text { elvesztése }\end{array}$ & $\begin{array}{l}\text { Férfivé válási rítus (szinte } \\
\text { mindig korcsoportonként); } \\
\text { diplomaosztó ünnepség }\end{array}$ & $\begin{array}{l}\text { Az egész társadalmat befo- } \\
\text { lyásoló hirtelen esemény } \\
\text { (forradalom kitörése, kato- } \\
\text { nai megszállás, természeti } \\
\text { katasztrófa) }\end{array}$ \\
\hline Időszak & $\begin{array}{l}\text { Kritikus életszakasz; puber- } \\
\text { tás, tinédzserkor; egyéni } \\
\text { vallási zarándoklat }\end{array}$ & $\begin{array}{l}\text { Olyan férfivé válási rítus, } \\
\text { amely hetekig vagy hóna- } \\
\text { pokig is tarthat; csoportos } \\
\text { zarándoklat; csoportos uta- } \\
\text { zás; kollégiumi élet }\end{array}$ & $\begin{array}{l}\text { Háború; polgárháború; for- } \\
\text { radalmi időszak; interreg- } \\
\text { num; járvány }\end{array}$ \\
\hline $\begin{array}{l}\text { Hosszabb } \\
\text { korszak }\end{array}$ & $\begin{array}{l}\text { Önként vagy kényszerből } \\
\text { „társadalmon kívülivé” vá- } \\
\text { lás; szerzetesi élet; az ikrek } \\
\text { néhány társadalomban }\end{array}$ & $\begin{array}{l}\text { Régi és új kultúrák közötti } \\
\text { átmeneti állapotban levő } \\
\text { egyházi közösség, etnikai } \\
\text { kisebbség, bevándorló cso- } \\
\text { port; a „normál struktúrák” } \\
\text { peremén élő, gyakran ve- } \\
\text { szélyesnek és/vagy szent- } \\
\text { nek tekintett csoport }\end{array}$ & $\begin{array}{l}\text { Elhúzódó háborúskodás; } \\
\text { tartósan instabil politikai } \\
\text { helyzet; össztársadalmi ide- } \\
\text { ológiai zürzavar; a liminali- } \\
\text { tás beépülése a struktú- } \\
\text { rákba }\end{array}$ \\
\hline
\end{tabular}

Forrás: Thomassen $(2009,17$.$) fel használásával saját szerkesztés.$

túl az is lényeges szempont, hogy az adott liminális entitás (egyén, csoport vagy társadalom) milyen mértékben tapasztalja meg a liminalitást. Véleménye szerint ez elsősorban abban ragadható meg, hogy a tartós struktúrákkal szemben mekkora befolyással bír a liminalitással együtt járó bizonytalanság.

E koncepcionális bővülés leglényegesebb eleme a tanulmányunk szempontjából az, hogy a liminalitás fogalma már nem csupán egyének vagy kisebbnagyobb csoportok, hanem akár egész társadalmak átmeneti állapotaira is alkalmazható 4 (lásd a táblázat jobb oldali oszlopát), hiszen munkánkban mi is erre teszünk kísérletet. Ezekben az esetekben a szóban forgó társadalom egésze átfogó válságot, a fennálló rend összeomlását éli meg: a liminalitás ekkor két stabil struktúra közti antistruktúraként értelmezhető, amely egyúttal jelentős társadalmi változásokat is lehetővé tesz. Lényeges kiemelni, hogy az egész társadalmakat, országokat érintő liminalitás bizonyos szempontból különbözik a kis létszámú közösségek korábban bemutatott rítusaitól (Thomassen 2009, 21-22.). A van Gennep és Turner által leírt rítusok esetében az abban résztvevők tisztában vannak vele, hogy liminális helyzetben vannak, amelyet előbb vagy utóbb maguk mögött fognak hagyni, továbbá mindig van egy szertartásmester, aki átsegíti őket ezen az állapoton. A társadalmak egészét érintő liminalitás esetében azonban egyrészt teljesen ismeretlen a jövő (vagyis az, amely a liminális sza- 
kaszt követni fogja), másrészt nincs olyan szertartásmester, aki korábban már keresztülment ezen a folyamaton, s így kivezethetné abból az embereket. Ezekben a helyzetekben a liminalitás veszélyes, kritikus időszakot jelenthet, melynek során vezető szerepre töro „önjelölt szertartásmesterek” (politikusok, diktátorok) léphetnek fel, akik a liminalitás fenntartásában, valamint az abban rejlő kreatív, konstruktív potenciál korlátozásában és/vagy annak kiaknázásában érdekeltek.

Ugyancsak a liminális állapotra, azaz a két stabil struktúra közti képlékeny antistruktúrára jellemző a Turner (1969) által is használt communitas kialakulása (1. ábra). Egy közösség életében akkor beszélhetünk communitasról, amikor annak valamennyi tagja osztozik a közösen átélt liminális tapasztalatban. (Ez a tapasztalat ugyanis - legalábbis ideiglenesen - mindenkit azonos szintre helyez, elmossa a társadalmi hierarchiák határait.) Turner $(1969,132$.$) a communitas$ három típusát különbözteti meg. Az első az egzisztenciális vagy spontán communitas, amelyet az összetartozás pillanatnyi - és gyorsan múló - élménye hoz létre (pl. ellenkulturális események során), a második a normatív communitas, amikor az előző spontán forma szervezettebbé, tartósabbá, a társadalmi rendszer részévé válik, míg a harmadik az ideológiai communitas, amely utópisztikus társadalommodelleket jelöl. Turner szerint a communitas jellemzője nemcsak a liminalitás, hanem egyúttal a marginalitás és a strukturális alávetettség is, s ezek együttesen kovácsolják össze a közösség tagjait.

Végezetül ugyancsak fontos kiemelni, hogy nemcsak liminális entitások és időszakok léteznek, hanem - ezekhez kapcsolódóan - a liminalitás helyeiröl, tereiröl is beszélhetünk (természetföldrajzi, politikai, gazdasági és kulturális értelemben egyaránt), az előzőekhez hasonlóan szintén a legkülönbözőbb léptékeken. A liminalitás térbelisége konkrét helyektől (pl. útkereszteződésektől, hidaktól, hotelszobáktól, bordélyházaktól, repülőterektől) kezdve nagyobb területeken, zónákon (pl. határsávokon, vitatott területeken, senki földjén) át akár egészen országokig, nagyobb makrorégiókig terjedhet (Thomassen 2009, 16.). E magától értetődő térbeli dimenzió fényében mégis meglepő, hogy a társadalomföldrajzi diszciplínában - számos egyéb társadalomtudományi területtel ellentétben - nem vált széles körben ismertté a fogalom. A földrajzos munkák közül a tanulmányunk témájával kapcsolatban elsősorban Czepczyński munkáit $(2008,2010)$ szükséges kiemelni, aki a (poszt)szocialista kontextus esetében támaszkodott Turner gondolataira. A következő fejezetekben az orosz expanziós törekvések példáján - ennél tágabb időkeretben vizsgálódva - magunk is a liminalitás tereinek bemutatására teszünk kísérletet.

\section{Új-Oroszország a Fekete-tenger partján}

Az orosz történetírásban a krími tatárok rettegett ellenfélként, több évszázados fenyegetésként jelennek meg (Heller 1996), a 19. és 20. század eseményei vi- 
szont az orosz nagyhatalmi politika áldozataivá tették őket (Williams 2000a, 2002). Mikor és hogyan változtak meg a struktúrák, amelyek hatására megfordult a szereplők helyzete?

Az altáji nyelvcsaládhoz tartozó, tatár nyelvet beszélő krími tatárok több évszázados társadalmi berendezkedése a törzsi szerveződésen alapult. A mongol Arany Horda alattvalóiként tértek át az iszlám hitre, önálló kánságuk e nomád államalakulat szétesésekor jött létre (Aydıngün, Aydıngün 2007). A Krími Tatár Kánság több évszázadig ellenállt az orosz hódításnak, folyamatos támadásai rettegésben tartották annak lakosságát (Katchanovski 2005). Az orosz hatalom óvatosságának oka a korabeli iszlám világ központjaként funkcionáló Oszmán Birodalom, melynek a krími tatárok alattvalói (adófizetői) voltak (Williams 2001). Katonai szolgálatuk fejében a közösségeik szervezésében nagyfokú belső önállóságot élveztek. Gazdasági tevékenységük alapját a lovasságuk adta, sajátos szimbiózisban éltek a Fekete-tenger északi partján fekvő nagy oszmán kereskedővárosokkal (Williams 2001), elsősorban Azovval: a krími tatárok rettegett hírét adó portyázásaik során a szláv és a balti (orosz, lengyel, litván) lakosságot fogták el és adták tovább Azov rabszolgapiacán.

A sikeresen terjeszkedő orosz hatalom alapjaiban változtatta meg a fennálló struktúrákat, liminalitást idézve elő a krími tatár közösségek életében. Az évszázadokon átívelő orosz-török háborúk hosszú sora nyomán alakult ki az orosz területi igény a Fekete-tengerre, sőt, annak legnagyobb városára, Isztambulra (Konstantinápolyra) is (Kirimli 2008). A katonai sikerek révén az oszmánoktól elhódított terület, az ún. Új-Oroszország egyre nagyobb kiterjedésűvé vált a Fekete-tenger mentén. A 18. században születő elnevezést eredetileg minden olyan területre alkalmazták, amely az egykori Arany Horda területén jelentett terjeszkedést (Heller 1996). A ritkán lakott végtelen sztyeppéken történő terjeszkedés megtestesítői a szigetként épülő erődvárosok (Voronyezs, Livni, Jelec, Belgorod, Oszkol, Kurszk) (Heller 1996). A nyomukban megjelenő orosz telepesek helyzete hosszú ideig igen kétséges volt a krími tatárok rablóhadjáratai miatt (Zaloznaya, Gerber 2012).

A 18. században I. Péter, majd II. Katalin a római (bizánci) impérium újraéledését hirdette, amit a gyakorlatban az egykori Konstantinápoly (akkor már Isztambul) elfoglalásával kívántak szentesíteni (Kirimli 2008). A Fekete-tengernél a hódításkor létező struktúrákat nem létezőnek, figyelmen kívül hagyható átmenetnek tekintették, sajátos liminalitást teremtve a meghódítottak életében. Az oszmán hatalom térségből való kiszorításának megvalósításakor „elnéztek" a krími tatárok feje felett, s úgy építették ki az új struktúrákat, mint ha a krími tatár közösségek nem is léteznének. Területük Oroszországhoz csatolását az orosz-török háborúkat lezáró békékben szentesítették, a két hatalom közötti egyezmény anélkül született és vált realitássá, hogy abban a krími tatárok számára bármilyen érdekérvényesítő szerep jutott volna.

A krími tatárok életében megjelenő liminalitás időszakában a régi (az oszmán hatalom) és az új (az orosz hatalom) markánsan elkülönült, a folytonosság 
látványosan megszakadt (Fisher 1967). Az antistruktúrákat hordozó hatalomváltás olyan gyarmatosítási tevékenységként jelent meg a térségben, amelyben az orosz állam hatalma jelképeként stratégiai jelentőségű helyszíneken új városokat, erődített helyeket épített, hátországukba pedig a termőföldeket feltörő telepeseket költöztetett át. Ezzel egy időben a régi központok hatalomvesztése érdekében látványosan növekedő, a megjelenésükben is impozáns új (ám az iszlám hódítás előtt itt létező települések romjain emelt) központokat alakítottak ki (közülük is kiemelkedik az 1794-ben alapított Odessza), amelyek újonnan betelepülő keresztény európai lakossága (Illés 2018) a régi (iszlám) hatalmi elitet ellensúlyozta a térségben.

Azov „megszűnése” (Boeck 2008) alapjaiban rengette meg a krími tatár közösséget, hiszen hagyományos életmódjuk gazdasági alapját veszítették el. Az oszmán-török háborúk eredményeként egykori uraik, az oszmánok lemondtak, az új hódítók pedig nem vettek tudomást róluk. Az orosz hatalom (,szertartásmesterként") úgy hajtotta végre az átmenet rítusát, hogy figyelmen kívül hagyta a beavatáson átesőket. Az uralomváltással megjelenő új struktúrák nem tették lehetővé számukra a hagyományos életmódjuk további fenntartását, beilleszkedésük csak markáns változtatások árán valósulhatott meg. A közösség nagy része inkább a régi kereteket biztosító, oszmán fennhatóságú területekre vándorlást választotta (Aydıngün, Aydıngün 2007; Kirimli 2008), s csak kisebb részük vállalta az új struktúrákhoz való igazodást, az életmódváltást.

A maradók rövid időn belül beilleszkedtek az új társadalmi keretek közé, vállalták az orosz autoritás - mint „szertartásmester” - által nyújtott feltételeknek való megfelelést. A vérségi kapcsolatok alapján szerveződő közösségi kapcsolatok tovább éltek, de korábbi nomád életmódjuk helyett a Krím félsziget hegységeinek tengerparti előterében létező, főként szőlö- és dohánytermesztéssel foglalkozó falvaik váltak a közösségeik alapjává, míg a legelőterületeken megvalósították az évszakosan legelőváltó (transzhumáló) pásztorkodást, félnomád jellegével megőrizve korábbi életük bizonyos elemeit (Williams 2001). A liminalitásban rejlő új lehetőségek születését jelzi az az európai szellemi áramlatokhoz való igazodásból induló, a krími tatárok által végzett reformtevékenység, amely az egész türk nyelvű iszlám közösségre nagy hatást tett a 19. században (Ortayli 1991). Az új struktúrák átvételével lezáruló liminalitás a 20. században ismételten jelentkezett a teljes krími tatár közösség életében, alapjaiban változtatta meg társadalmuk külvilághoz való viszonyát.

\section{Az orosz és a szovjet hatalom találkozása a Kaukázussal: a csecsen példa}

A Kaukázus északi előtere a közelmúltban is polgárháborús hadszíntér volt. A nemzetközi közvélemény a konfliktust az itt élő csecsenekkel azonosítja, akiket 
2001 óta kapcsolatba hoznak az iszlám terrorizmussal (Souleimanov, Dytrich 2008). A közösségeikre jellemző bizonytalan struktúrákat teremtő liminalitás és az ennek eredményeként megélt communitasélmény azonban valójában nem a közelmúlt eseményeiből fakad.

A kaukázusi nyelvek közé tartozó nah nyelvet beszélő csecsenek (Nichols 2004) a Kaukázus északi előterében élő kaukázusi népek legnagyobb közössége. ${ }^{5}$ Településterületük az államalakulatokat létrehozó hatalmi központoktól távol helyezkedett el, ezért azok fennhatósága évszázadokig nem jelentett lényegi külső beavatkozást az életükbe, az archaikus struktúrák a modernizáció beköszöntéig zavartalanul müködhettek. Törzsi alapú társadalmuk iszlám hite a Balkánon is ismert szúfi irányzatokhoz köti közösségüket (Dam 2011). Félnomád életmódjukban egyszerre volt jelen a transzhumáló pásztorkodás és a sík területek állandó településeinek mezőgazdasági tevékenysége. A hatalom a férfiak foglalkozásából adódóan a hegyvidéki területeken koncentrálódott az év jelentős részében; ennek megfelelően a csecsen közösségek életében jellegzetes vertikális tagolódás figyelhető meg. A hátországként funkcionáló mezőgazdasági területek kiváló terméshozamukkal kiemelkedő jólétet, megnövekedett állatállományt, népesebb közösségeket tartottak fenn (Nichols 2004). Ez a tény önmagában is kiemelte őket a többi nép közül a hódítók szemében, azonban még inkább döntő volt a földrajzi helyzetük, területük ugyanis közvetlenül érintkezett azzal a zónával, amelyen keresztül az orosz hatalom kapcsolatban állt a Kaukázuson túli területekkel: az orosz hadsereg felvonulási területének határán éltek (Heller 1996).

A fent bemutatott, preliminalitásként értelmezhető helyzetben az orosz hatalom folyamatos fenyegetésként élte meg létüket, ezért igyekeztek az általuk szabályozott keretek közé szorítani őket. A kaukázusi népek hagyományos struktúráit elbizonytalanító orosz terjeszkedés a 20. század eseményeinek hatására elhúzódó liminalitást eredményezett a csecsenek társadalmában. Egy olyan felfokozott, a hatalommal szemben állandó feszültséget generáló állapotot idézett elő a társadalom életében, amelynek hatására minden alkalommal fellázadtak a hatalommal szemben (Blandy 1996), ha érezték annak gyengülését. Az orosz hadsereg nyomában megjelenő orosz telepesek és a kiépülő közigazgatás a csecsen törzsek érdekeit sértette, amire katonai támadásokkal, portyázásokkal válaszoltak. Az elbizonytalanodó helyzetükből fakadó védekezés adta az alapját annak a csecsen öntudatnak, amely a többi hegylakó nép laza törzsi szerveződéséhez képest szorosabb kapcsolatot teremtett a csecsen törzsek között, és a törzseken felüli kollektív azonosságtudatot is eredményezett (Nichols 2004). A formálódó antistruktúrát erősítette, hogy az orosz hatalom (mint „szertartásmester”) beavatási kísérletét váratlan ellenreakció hiúsította meg az iszlám hit oldaláról. A kaukázusi vallási mozgalom szent háborút hirdetett a hódítók ellen, ami nem várt egységet teremtett a kaukázusi népek között (Heller 1996). Az expanziót folytató hatalmat ez még inkább arra sarkallta, hogy lehetőség szerint tüntesse el a rablónak aposztrofált közösségeket (Gould 2014). 
Az egyre jelentősebb összefogást és katonai ellenállást tanúsító csecsen területeket hivatalosan 1854-ben csatolták Oroszországhoz. Az orosz autoritás „,szertartásmesterei" fölénybe kerültek, megindult az orosz közigazgatás kiépítése a csecsen területeken, aminek manifesztuma a Groznij erődvárosából kiépülő központ (a város neve „félelmetest”, „rettenetest” jelent). Az új hatalom engedelmes alattvalói azonban a betelepülő orosz lakosságból kerültek ki. A vérségi kapcsolatok nyomán szerveződő csecsen törzsi társadalom tovább élt, de a hatalom által korlátozott gazdasági keretek között, ami állandó feszültségforrás volt a helyi közösségek és a központi hatalom helyi képviselői között.

Az első világháború idején születő Szovjetunió örökölte ezt a megoldatlan kérdést: a Csecsen-Ingus Autonóm Szovjet Szövetségi Köztársaság területén 1921-1941 között tizenkét nagyobb felkelés tört ki, ezen felül az itt lakók számtalan módon kifejezték a bolsevik hatalommal való szembenállásukat (Werth 2006). Ennek oka főként a gazdasági struktúrák erőszakos megváltoztatási kísérleteiben, a szovjetizálásban keresendő, melynek során a földtulajdon megszüntetésével és a kolhozosítással a szovjet hatalom a hagyományos életmódjuk ellen indított támadást. A második világháború alatt a Kaukázus környéki kőolajlelőhelyek növelték a térség stratégiai jelentőségét (Burds 2007), ami a korabeli szovjet vezetést (azaz Sztálint) az évtizedek óta húzódó konfliktus hatékony és gyors megoldására sarkallta. Annak ellenére, hogy a szovjet erőkkel együtt harcoltak, a csecsen félkatonai alakulatokat mégis kollaborálással vádolták, majd a kollektív bűnösség elvét alkalmazva elhatározták a teljes csecsen közösség deportálását: ennek eredményeként 1944 elején 500 ezer embert ${ }^{6}$ vittek el Kazahsztán és Kirgizisztán területére (Werth 2006).

A szovjet hatalom „szertartásmesterként” kiszakította a közösséget eredeti lakhelyéről (megújítva ezzel az elkülönülés preliminális szakaszát), majd létrehozta a liminalitás szigeteiként müködő spectelepeket, amelyekben az új struktúrák befogadásának és a szovjet ideológiához kötődő identitás kialakításának hatékonyabb eszközét látták. A spectelepeken élők visszautasítottak minden együttmüködést, állandó volt a munka megtagadása, a lázadás, az őrzőkkel szembeni atrocitás (Werth 2006). A kazah és kirgiz területek csecsen spectelepein kialakulóban volt egy új Kaukázus (tehát úgy tűnt, hogy a szovjet „,szertartásmestert" a csecsen válthatja fel): a törzsi szokásjog mentén önmagukat újraszervező közösségek kizárták a szovjet diktatúra érvényesülését a mindennapokban, a hatalom a spectelepek határain kívül rekedt.

A központi hatóságok csak Sztálin halála után ismerték el a kudarcot, 1957-ben visszaállították a Csecsen-Ingus ASZSZK-t és megszervezték a deportáltak visszaszállítását a Kaukázusba (Blandy 1996). A visszatérők azonosságtudatában a rendszerrel való szembenállás továbbra is kiemelkedő motívum maradt, amelyet a modernizációval beköszöntő új életformák sem tudtak felszámolni (Williams 2000b). Ennek manifesztumaként értelmezhetjük a rendszerváltás utáni két orosz-csecsen háborút, amelyek az önálló Csecsenföld és a csecsen autonómia elismerését (tehát a csecsen struktúrák érvényesülését, de egyben az orosz közigazgatási rendszerbe való illeszkedését) eredményezték. 


\section{A balti államok és a rendszerváltás}

Az észtek, lettek és litvánok az orosz hódítást megelőző évszázadokban olyan európai struktúrákhoz kapcsolódtak, amelyek a kapitalizmus kibontakozásának idején számos előnyhöz juttatták az itt élőket. A Hanza-városok, a Német Lovagrend, Svédország, Dánia és Lengyelország érdekszférájához tartozó területen nagyobb terepet kapott az önigazgatás, a városi lét, a távolsági tengeri kereskedelemből adódó kiterjedt kapcsolatrendszer. Mindezek az előnyök valójában nem az észt, lett és litván lakosok kezében voltak, de hatásaik az ő életükben is jelentkeztek. A 18. századi hatalomváltás a túlnyomóan vidéki, agrártevékenységeket folytató közösségek (Elson 1997) „feje felett” történt, az orosz hatalom a központokban szorította ki a régit és igyekezett átvenni annak szerepköreit. Mindez azonban nem járt a struktúrák markáns változtatásával, hiszen az Orosz Birodalom érdeke éppen a fennálló keretek orosz irányítással megvalósuló tovább élése volt.

Az első világháborúban kialakuló különleges politikai helyzet lehetővé tette a független Észtország, Lettország és Litvánia megalakulását. A két világháború között megszülető balti államok elnevezés alatt létező három ország népességszáma együttesen alig haladta meg az 5 millió föt (Piip 1933). Az orosz fennhatóság alól szabaduló térség tovább ápolta a jól múködő kapcsolatokat a skandináv államokkal, elsősorban Svédországgal (Piip 1933), a területükön élő jelentős számú orosz lakosságot az új államok teljes jogú polgárainak tekintették (Saburova 1955). A vezetés ugyan változott, de a mindennapokban a folytonosság továbbra is megmaradt.

A balti államok életében preliminalitásként értelmezhető az 1940-ben szovjet kényszer hatására történő csatlakozás a Szovjetunióhoz (Heller, Nyekrics 1996), amely után 220000 föt (a három állam összlakosságának 4\%-a) deportáltak a balti területekről 1941-ig (Saburova 1955). ${ }^{7}$ A „,szertartásmesterként” fellépő szovjet hatalom ezzel megkezdte a felkészítést a gyökeres átalakításra. A régi struktúrák szisztematikus rombolását a második világháború után hajtották végre. A korábbi gazdasági kapcsolatok lehetőségét megszüntették, a keleti blokkon belül is korlátozták a kapcsolataikat - mindenben Moszkva felé fordították őket. A balti államok agrárjellegű társadalmát a szovjetizálás folyamatában a kollektivizálás érintette rendkívül érzékenyen (Senn 1958). A bizonytalan helyzetben formálódó communitas mutatkozik meg az itt élők heves ellenállásában a kollektív földtulajdont kialakítani kívánó hatóságokkal szemben, amely a nagyarányú deportálások hatására hagyott alább: a második világháborút követő három évben több mint 350000 embert költöztettek Szibériába (Saburova 1955).

A társadalom agrárjellegét erőltetett iparosítással, új gyárak létesítésével, a korábbi paraszti foglalkozásúak ipari munkásokként való tömeges foglalkoztatásával változtatták meg az 1950-es években. A balti államok pravoszláv hittől eltérő (tehát nyugati hatásra protestáns, római katolikus, görög katolikus) val- 
lási közösségeinek müködését minden lehetséges módon igyekeztek korlátozni (Saburova 1955; Senn 1958). A szovjet hatalom sajátos oroszosítási kísérlete is éreztette hatását az oktatásban (Elson 1997). Ezt erősítette a megszállással és a nagyarányú iparosítással a balti államok területére - különösen Észtországba és Lettországba - áramló (elsősorban) orosz lakosság (Elson 1997).

A Sztálin halálát követő fordulat e folyamatok ellenében hatott, a társadalom életében külső hatásra beálló liminalitás így több évtizedre elhúzódott. A változó központi politika lazított a balti államok zártságán: a Szibériába deportáltak ugyan nem térhettek haza, de felvehették a kapcsolatot az otthon maradottakkal, a nyugaton élő emigráns közösségektől érkező hírek (és csomagok) pedig a szovjet propagandáétól eltérő nyugatképet közvetítettek. Mindez erősítette a balti államok különálló nemzeti érzését és egyben a változások reményét, a várakozás állapotát.

A Szovjetuniótól való elszakadásukat 1991-ben deklarálták a balti államok. A megváltozott geopolitikai helyzethez igazodva kérték felvételüket az Európai Unióba, a korábbi megszállókkal szembeni védelem biztosítása érdekében pedig a NATO-ba. Mindkét esetben hosszú éveket kellett várniuk, amíg a tagság végül megvalósult (Black 1999). Egyes szerzők ezt sajátos liminális helyzetükkel magyarázzák (Nyugat- és Kelet-Európa határa), sőt, az elhúzódó csatlakozási tárgyalásokat a nyugati világba való beavatási rítus előtti liminalitásként is értelmezik (Mälksoo 2010). A szovjet időszak rendkívül erőteljes - a megszálló hatalom elleni - negatív attitüdöt, valamint a helyi orosz lakossággal szembeni erős ellenérzést váltott ki. Különösen Észtországban és Lettországban vált feszültté a helyzet, ahol a szovjet időkben bevándorló népesség aránya igen magas volt. A nemzeti létben, illetve az ennek manifesztumaként ismét létező önálló államterületen a bevándorlók jelenlétét idegen testként kezelték, aminek kifejezése végül az állampolgárság kérdésében csúcsosodott ki (Elson 1997).

Az ezredfordulót követően a NATO és az európai uniós csatlakozás a balti országok számára a konszolidáció éveit hozta el, ami egyrészt az orosz hódítás előtt hagyományosnak tekinthető nyugati gazdasági kapcsolatok létesítését, a nemzetközi kapcsolatok tágítását, másrészt a többség és a kisebbség közötti feszültségek mérséklődését jelenti. Az elmúlt évtizedek elhúzódó liminalitása azonban megváltoztatta a társadalmat. A balti népek identitásában kiemelkedő jelentősége van az európaiság, a nyugati kapcsolatok hangoztatásának, az orosz évszázadok előtti történelmi emlékek ápolásának, miközben továbbra is jelentős az orosz kisebbségtől való elkülönülésük (még mindig vannak állampolgárság nélküli lakosai a balti államoknak), a megszálló hatalom kegyetlenkedéseinek emlékére pedig minden lehetséges módon felhívják a figyelmet. A szovjet időszak vallásellenessége is szerepet játszik abban, hogy a balti államok társadalmában - Észtországban leginkább, Litvániában a legkevésbé - kiemelkedő a szekularizáció mértéke (Bruce 2000). 


\section{Az önmagában való liminalitás: Ukrajna}

Az egykori szovjet tagköztársaságban a rendszerváltás után elégtelenül működő struktúrák szétesése a szemünk láttára ment végbe, a háborús konfliktusban megjelenő liminalitás azonban mély gyökerekkel rendelkezik az ukrán társadalomban. Ukrajna a létét a Szovjetuniónak köszönhette, korábban évszázadokon át az orosz állam része volt. Ennek nyomán mindvégig kérdéses volt, hogy a moszkvai központi vezetés a Szovjetunió felbomlásával mennyire ad teret Ukrajna független államiságának. Ez a bizonytalanság öltött testet az elmúlt évek polgárháborújában és az orosz katonai beavatkozásban.

A keleti szláv nyelvet beszélő, ortodox vallású ukránok identitásában az orosztól eltérő vonások több hatás eredőjeként értelmezhetők. Az elhelyezkedésből adódó eltérő kapcsolatok, a 14. század óta önálló egyházszervezet, a tatárjárás, majd a litván hódítások erősítették a különállást (Heller 1996). Ukrajna - mint önálló állam - létét a kozákok alapozták meg a 17. században (Heller 1996), akik a függetlenség kinyilvánítása után a pravoszláv orosz fennhatóságot fogadták el. Az ún. kisorosz önigazgatást II. Katalin számolta fel a 18. században. Az önálló ukrán tagköztársaság létrejöttét az első világháború viszontagságai közepette a bolsevikoknak nem sikerült megakadályozni: az 1920-ban kötött szerződés az Ukrán Szovjet Szocialista Köztársaságot a többi tagköztársasághoz képest előnyökkel kapcsolta a Szovjetunióhoz (Heller, Nyekrics 1996).

Mindezek alapján talán az sem túlzás, ha az ukrán nép történetét folyamatos liminalitásként értelmezzük. ${ }^{8}$ Mi most mégis egy szűkebb értelmezést keresünk, és amellett érvelünk, hogy az ukrán államban élők az 1917-es megalakulástól kezdve kollektív sokkhatások sorozataként élhették meg a korábbi - nem egységes állami keretek között létező - társadalmi struktúráik erőszakos szétverését. A felvázolt határhelyzetből ered sajátos azonosságtudatuk, amely éppen annak köszönhette több évszázados fennmaradását, hogy az ukrán nép a mindenkori államalakulatok peremén élt (maga az ország és a nép neve is innen ered: okraina = valaminek a széle, vége). Ennek egyik eleme volt a szabad paraszti lét, amely különböző érdekek okán, ám mindig kapott engedményeket. Az itt élők számára a liminalitást közvetlenül megelőző, felkészíto szakasz az első világháború, amely ellehetetlenítette gazdasági tevékenységeiket, így az önálló állami lét tulajdonképpen meg sem érinthette az itt élők zömét, akik a háborús pusztítások és a mezőgazdasági termelés leállása nyomán érzékeny veszteségeket szenvedtek el az 1920-21-es nagy éhínségben. Miután Sztálin 1929-ben meghirdette a kollektivizálás gyors végrehajtását, ez Ukrajna területén a korábbi gazdasági struktúrák teljes megszüntetését, emberek tömegeinek deportálását, majd az 1932-33-as nagy éhínséget, milliók éhenhalását eredményezte (Katchanovski 2010).

Az 1930-as években jellemző politikai tisztogatások az ukrán értelmiséget sem kímélték, majd a második világháború tovább fokozta óriási emberveszteségeiket (Katchanovski 2010). A háború utáni sztálini politika a kollaboráció 
vádjára alapozva ismét érzékeny csapást mért a helyi lakosságra. A háború alatt Ukrajna nyugati területein szerveződő nacionalisták kis közösségei évekig folytatták még a harcot (tehát a liminalitásban megélt communitas folyamatosan jelen volt a szovjet időkben), de ezzel csak fokozták a deportálások ütemét és a helyi lakosság szovjet hatalom általi, szó szerinti likvidálását. Mindezt tetézte a háborús pusztítások és a szokatlanul száraz időszak következtében megjelenő újabb éhínség 1946-ban és 1947-ben, amelyben a szovjet központi vezetés magára hagyta az ukrán tagköztársaságot, újabb milliós emberáldozatot okozva (Heller, Nyekrics 1996). Az ukrán tagköztársaság első évtizedeinek óriási demográfiai veszteségei adtak alapot a 20. század második felében az orosz népesség nagyarányú bevándorlásához, különösen az ország keleti, modern gazdasági szempontból sokkal jelentősebb, iparosodottabb területeire, lényegesen módosítva ezzel az állam korábbi, ukrán dominanciájú etnikai összetételét.

A létező communitas bizonyítékaként az ukrán nemzeti jellegü közösségi mozgalmak újra és újra megjelentek a Szovjetunió történetében, de a moszkvai központi vezetés mindig keményen leszámolt velük. Számos lehetősége volt viszont a helyi lakosságnak az etnikai identitás megélésére (nyelv, kultúra), valamint ünnepeik révén a communitas erősítésére. ${ }^{9}$ Az ukránok azonban nemcsak nacionalista megmozdulásaik elfojtása okán, hanem kultúrájukban is folyamatosan fenyegetve érezték magukat. Az orosz nyelv kötelező oktatása, az orosz irodalom, az orosz szerzők és művészek előtérbe helyezése gyengítette az oroszhoz nagyon hasonlító ukrán nyelv tovább élésének lehetőségét (Korotich 1992), a helyi egyház müködésének ellehetetlenítése pedig a pravoszláv (és görög katolikus) hitükben való különállásukat veszélyeztette (Gee 1995).

A bizonytalan struktúrák a rendszerváltással sem változtak meg. Az ország működését 1991-es függetlensége óta a végletekig nehezíti kétarcúsága (Bottlik, Karácsonyi 2018).$^{10}$ A nyugati, gazdaságilag kevésbé számottevő területek ukrán többségü, nyugatbarát, nyugati nyitást szorgalmazó politikai irányvonalával szemben jelentkezik a jelentős orosz kisebbséggel rendelkező, gazdaságilag kiemelkedő fontosságú keleti területek oroszbarát politikai orientációja (Ponarin 2000). E kettősség kezelése ellehetetleníti a parlamentáris demokrácia múködtetését, megakadályozza a liminalitásban élő társadalom konszolidációját. A bizonytalan helyzetben az ország orosz kisebbsége és a többségi nemzet között feszülő ellentétek polgárháborúba torkolltak a keletukrán területeken. Az aktivizálódó orosz külpolitika és a radikalizálódó ukrajnai orosz kisebbség eredőjeként értelmezhető a rendszerváltás óta vitatott hovatartozású Krím félsziget orosz annexiója és a terület Ukrajnától való elszakadása (Mearsheimer 2014).

A szovjet időszak előtti orosz állami vezetés az orosz etnikai tér szerves részének tekintette az ukrán államot. A Szovjetunió keretein belül megvalósulhatott az ukrán nemzet formálódása, de csak szigorúan ellenőrzött keretek között, a lehető legszorosabb kapcsolatban Oroszországgal. Önálló államként a Független Államok Közösségén belül jött létre 1991-ben, amelynek keretrendszerében az orosz hatalom hathatós fellépéssel fogja szorosra a tagállami kapcsolatokat. 
A rendszerváltás után is elhúzódó liminalitásban a nyugat politikája is érintett azáltal, hogy teret engedett Ukrajna Európai Unióhoz való közeledésének és NATO-hoz való esetleges csatlakozásának, s ezzel lényegében új „szertartásmesterként" lépett fel az ukránok életében. Az orosz politika viszont aláássa a nyugatbarát politikát Ukrajnában, míg az oroszbarát erőket hathatós (gazdasági és katonai) eszközökkel támogatja (Izhak 2016). A Krím Oroszországhoz csatolásával visszaállt az Ukrán SZSZK 1945-1953 között fennálló területe, amelynek határait az orosz vezetés egyelőre tiszteletben tartja (nem reagálnak a keletukrajnai oroszbarát fegyveres erők azon kérésére, hogy hadseregükkel vonuljanak be az általuk irányított területekre, és a Krímhez hasonlóan csatolják azokat Oroszországhoz). A szovjet idők sokkhatásai után (amelyet tulajdonképpen újraélesztett a jelenlegi háborús helyzet) az ukrán társadalom számára az Oroszországhoz füződő viszony rendezése nehezen megoldható, ami hosszú időre feltételezi a liminalitás elhúzódását.

\section{Összefoglalás, kitekintés}

Tanulmányunkban a Victor Turner által „újrafelfedezett” liminalitás elméletét alkalmaztuk az orosz expanzió által érintett területeken, különböző történelmi korszakokban. A koncepció társadalomföldrajzi alkalmazhatóságához többek között Szakolczai $(2000,2003,2009)$ és Thomassen $(2006,2009,2015)$ munkái adtak segítséget, akik továbbgondolták és különféle (tágabb) társadalmi folyamatok magyarázására használták Turner elméletét. Munkánkban kizárólag az általunk kiválasztott etnikus közösségekre koncentráltunk, az adott kor orosz (vagy szovjet) társadalmának - vagyis az expanziós „térfélnek” - az elemzésére nem vállalkoztunk. Tisztában voltunk azzal is, hogy az általunk vizsgált közösségek társadalmi dinamikájának részletes bemutatására nincs lehetőségünk, ezért sokkal inkább a társadalmi „állapot” elemzésére törekedtünk. Értelmezésünk szerint a liminalitás időtartama nem beláthatatlan, a társadalmak többkevesebb sikerrel mindenhol elkezdik kialakítani az új struktúrákat, miközben az etnikus csoport identitásnarratívái is módosulnak, ezek pedig elvezethetnek a „küszöb átlépéséhez”, a liminalitás végéhez. Ennél fogva példáink esetében a „permanens liminalitás” fogalmát nem tartottuk relevánsnak, azzal a kiegészítéssel, hogy a liminalitás időtartama nehezen megjósolható, amint azt az ukrán eset is bizonyítja.

Négy példán keresztül mutattuk be a liminalitás tereit, melynek során igyekeztünk elkerülni a „territorialitás csapdáját” (Agnew 1994), azaz nem hagytuk figyelmen kívül az általunk vizsgált területek történelmi kapcsolatait, társadalmi és kulturális mintázatait. A Krím, a Kaukázus, a Baltikum és Ukrajna heterogén etnikai térszerkezettel jellemezhető térségek, a közösségek „körülírása" és a kialakítandó politikai keretek tematizálták a modern nemzetté válás 
folyamatát és gyakran keresztezték a nagyhatalmak érdekeit (Bottlik 2016). A kis népek és az orosz birodalom érdekellentéteiből olyan konfliktusok keletkeztek, melyek egyes közösségeket a liminalitás állapotába(n) marasztaltak.

Az orosz expanzió által kiváltott liminális állapotok az aktuális társadalom, kultúra vagy az identitás szövetében keletkező kisebb-nagyobb szakadásként is értelmezhetők, az ezek befoldozására tett kísérletek pedig a hosszabb-rövidebb ideig tartó liminális szakaszok. Az orosz hatalom megjelenése után a strukturális alsóbbrendűség állapotába kerülő közösségek autonómiaigénye, tradíciókhoz való ragaszkodása vagy identitáskeresése az újonnan megszilárduló strukturális helyzetek birtokosai számára veszélyesnek és anarchikusnak tűnnek, ezért előírásokkal, tiltásokkal, szabályokkal próbálják ellensúlyozni azokat. Az új logika szerint a belső kohézió erősítése és a regionális különbségek eltüntetése érdekében intézményesülő tér (Paasi 1997) a hatalom által marginalizált csoportok transzgresszióját (eredeti jelentés szerint: „határsértés”, „áthágás”, „túllépés”) váltja ki (Cresswell 1996). Az új adminisztráció által ellenőrzött terekben a normalitás és a rend ellen ható szabályszegések gyakran nem tudatosak, hanem az összeegyeztethetetlen struktúrák súrlódásának szikrázó felületei. A transzgresszív viselkedés azonban újabb válaszokat vált ki a hatalom részéről, létrehozva a „strukturális erőszak” (Galtung 1969) kreatív formáit. A helyi nyelvek, a vallás, a nemzeti kultúra háttérbe szorítása és a társadalmi ranglétrán való nehezebb előrejutás mindegyik általunk bemutatott területen jellemző, ami az újonnan kialakított strukturális logika következménye. A liminális térben fokozódó ellenállás azonban mind a négy területen addig eszkalálódik, amíg az erőszakos események (lázadások, összecsapások és deportálások) tűnnek az egyetlen megoldásnak.

A mindenkori orosz birodalmi tekintet más problémákkal szembesül. A hatalmi centrum legnagyobb kihívása az államot keretező heterogén, fragmentált, több értelemben véve is periferikus övezet irányítása és „konszolidálása”, ezért az elnyomó hatalmi technikák mindig igazolást nyernek (Martínez 2013). „Ez nemcsak a centrum-periféria konfliktusa, hanem a rend és az anarchia, a kozmosz és a káosz, illetve a struktúra és az entrópia ellentéte. A termodinamika 2. tétele szerint azonban végül az entrópia érvényesül" (Medvedev 1997, 527.). Úgy tűnik azonban, hogy egy-egy közösség képes úrrá lenni az anarchikus, kaotikus állapotokon, újra átlépve a küszöböt a posztliminális fázisba érkezve, igaz - a példáink esetében - rengeteg szenvedés árán. Az orosz állam és társadalom a perifériáktól függően fejlődött ki, utóbbiak az elhúzódó liminális állapotok jegyeit hordozzák, ezért folyamatosan jelen vannak a politikai diskurzusokban és a hatalmi narratívákban (Martínez 2013).

A liminalitásnak sokféle kulturális megnyilvánulása lehetséges, ezek közül kiemelkedik a turneri communitas. Nem véletlen, hogy a példáinkban ezt kevésbé hangsúlyoztuk. A communitas az emberek kölcsönös összekapcsolódásának elevenségét képviseli (Turner 1969), ahol a személyes kapcsolatok felértékelődnek, ennél fogva a kis közösségek sajátja, társadalmi szinten nem vagy 
csak nehezen értelmezhető. A szovjet történelem legsötétebb fejezeteihez (és mind a négy példánkhoz) kapcsolódó deportálások következményeként azonban a hazájuktól távol kerülő száműzöttek összetartó kis közösségeiben megjelent a communitas, a csecsenek esetében pedig identitáskonstruáló erővel bírt. Az ukrán narancsos forradalom idején, a kijevi Függetlenség terén szerveződő spontán communitas is ezek közé a példák közé tartozik. A liminális állapot általában kedvez a communitas kialakulásának, e példák feltárása azonban túlmutat tanulmányunk keretein.

Több hasonlóság is felfedezhető a Krím, a Kaukázus északi előtere, a Baltikum és Ukrajna általunk kiválasztott és jellemzett liminális állapotai között. Az expanzió logikus velejárói az orosz katonaság és a telepesek jelenléte, a mindenhol felbukkanó oroszosító törekvések és a deportálások. Az új regionális hatalmi központok kiépítése azonban csak a Krím félszigeten és Csecsenföldön jellemző (pl. Szevasztopol, Groznij esetében). A szovjet hatalom erőszakos társadalom- és gazdaságpolitikája a régi struktúrák lebontásának kézenfekvő eszközévé vált. Mivel a liminális állapot a leigázott társadalmak számára „kényelmetlen”, ezért a szilárd struktúrák és a stabilitás érdekében módosítanak életmódjukon és identitásukon, megpróbálnak alkalmazkodni az új viszonyokhoz.

A hasonlóságok mellett természetesen különbségek, egyedi jellemvonások is megfigyelhetők. A nyelvi, vallási és kulturális transzferzónaként jellemezhető Fekete-tenger északi partvidékén (Kőszegi 2018) a krími tatárok elképzelt terének folytonosságát az épülő erődvárosok szigetszerüen felszabdalták. Az így létrejövő térmozaik elkülönült egységekké degradálta az addig egységesnek látott, kezelt és használt térséget, így hozva létre a liminalitás krími tereit. A Csecsen-Ingus ASZSZK megalakítása az új struktúra megteremtését hivatott elősegíteni, a szovjet hatalom egyoldalú és rugalmatlan próbálkozása azonban nem volt képes megszüntetni a Csecsenföldön állandósult liminalitást. A Baltikumban a liminalitás áthelyeződése figyelhető meg: a Szovjetunió felbomlása után az addig küszöbhelyzetben lévő észtek, lettek és litvánok saját nemzetállamukon belül posztliminális fázisba kerültek, a kisebbségi léttel szembesülő orosz lakosság pedig a liminalitás állapotával kezdett el ismerkedni.

Végezetül, összegzésként az általunk vizsgált négy területen a liminalitás, valamint az azt megelőző és azt követő állapotok legfontosabb jellemvonásait a 2. táblázatban foglaljuk össze. 
2. táblázat: A liminalitás szakaszjellemzői a tárgyalt térségekben

Main characteristics of the stages of liminality in the case study areas

\begin{tabular}{|c|c|c|c|c|c|}
\hline Terület & $\begin{array}{l}\text { Közös- } \\
\text { ség }\end{array}$ & $\begin{array}{c}\text { Liminális } \\
\text { korszak }\end{array}$ & $\begin{array}{c}\text { Liminalitás elötti } \\
\text { állapot }\end{array}$ & Liminális állapot & $\begin{array}{c}\text { Liminalitás utáni } \\
\text { állapot }\end{array}$ \\
\hline $\begin{array}{l}\text { Fekete-ten- } \\
\text { ger északi } \\
\text { partvidéke, } \\
\text { Krími Kán- } \\
\text { ság, „Új- } \\
\text { Oroszor- } \\
\text { szág” }\end{array}$ & $\begin{array}{l}\text { Krími } \\
\text { tatár }\end{array}$ & $\begin{array}{l}\text { 18-19. } \\
\text { század }\end{array}$ & $\begin{array}{l}\text { Nomád pásztorko- } \\
\text { dás, portyázások, } \\
\text { rabszolga-keres- } \\
\text { kedelem }\end{array}$ & $\begin{array}{l}\text { Orosz telepesek megjele- } \\
\text { nése, a kereskedelem ha- } \\
\text { nyatlása, az egységes etno- } \\
\text { territórium felszabdalása, } \\
\text { régi központok megszü- } \\
\text { nése, a terület Oroszor- } \\
\text { szághoz való csatolása, ki- } \\
\text { vándorlás }\end{array}$ & $\begin{array}{l}\text { A tengerparti telepü- } \\
\text { lések felértékelődése, } \\
\text { szőlö- és dohányter- } \\
\text { mesztés, legelőváltó } \\
\text { pásztorkodás, vallási } \\
\text { megújhodás: az isz- } \\
\text { lám reformja és an- } \\
\text { nak sikeres elterjesz- } \\
\text { tése }\end{array}$ \\
\hline $\begin{array}{l}\text { A Kaukázus } \\
\text { északi elő- } \\
\text { tere }\end{array}$ & $\begin{array}{l}\text { Cse- } \\
\text { csen }\end{array}$ & $\begin{array}{l}\text { 19-20. } \\
\text { század }\end{array}$ & $\begin{array}{l}\text { Félnomád pász- } \\
\text { torkodás és nö- } \\
\text { vénytermesztés, } \\
\text { az alföld és a } \\
\text { hegyvidék szerves } \\
\text { kapcsolata, törzsi } \\
\text { szerveződés }\end{array}$ & $\begin{array}{l}\text { Az orosz hadsereg és a te- } \\
\text { lepesek megjelenése, az új } \\
\text { orosz közigazgatás meg- } \\
\text { szervezése, csecsen lázadá- } \\
\text { sok, szent háború, új ha- } \\
\text { talmi központ létrehozása, } \\
\text { kolhozosítás, deportálás, } \\
\text { rendszerváltás utáni } \\
\text { orosz-csecsen háborúk }\end{array}$ & $\begin{array}{l}\text { Kiegyezés az orosz } \\
\text { hatalommal, nagy- } \\
\text { fokú autonómia, a } \\
\text { csecsen és az orosz } \\
\text { (politikai, adminiszt- } \\
\text { rációs, társadalmi és } \\
\text { szimbolikus) struktú- } \\
\text { rák egymáshoz illesz- } \\
\text { tése }\end{array}$ \\
\hline Baltikum & $\begin{array}{l}\text { Észt, } \\
\text { lett, } \\
\text { litván }\end{array}$ & $\begin{array}{l}20 . \\
\text { század }\end{array}$ & $\begin{array}{l}\text { Különböző euró- } \\
\text { pai hatalmak } \\
\text { fennhatósága mel- } \\
\text { lett többnyire vi- } \\
\text { déken élő, agrár- } \\
\text { tevékenységet } \\
\text { folytató közössé- } \\
\text { gek, az első világ- } \\
\text { háború után nem- } \\
\text { zetállami keretek }\end{array}$ & $\begin{array}{l}\text { A Szovjetunióhoz való } \\
\text { „csatlakozás”, deportálá- } \\
\text { sok, a mezőgazdaság kol- } \\
\text { lektivizálása, erőszakos } \\
\text { iparosítás, nem pravoszláv } \\
\text { vallási közösségek műkö- } \\
\text { désének korlátozása, oro- } \\
\text { szosítás }\end{array}$ & $\begin{array}{l}\text { A Szovjetuniótól való } \\
\text { elszakadás, EU- és } \\
\text { NATO-taggá válás, az } \\
\text { orosz nemzetiségű } \\
\text { lakosság állampol- } \\
\text { gárságának rende- } \\
\text { zése, az európai iden- } \\
\text { titástudat erősödése }\end{array}$ \\
\hline Ukrajna & Ukrán & $\begin{array}{l}\text { 20-21. } \\
\text { század }\end{array}$ & $\begin{array}{l}\text { Szabad paraszti } \\
\text { lét, részleges lehe- } \\
\text { tőség az önigazga- } \\
\text { tásra, az ukrán } \\
\text { nemzeti identitás } \\
\text { kialakulása }\end{array}$ & $\begin{array}{l}\text { A szovjet hatalom megjele- } \\
\text { nése, éhínségek, kollektivi- } \\
\text { zálás, deportálások, hábo- } \\
\text { rús pusztítás és ember- } \\
\text { veszteség, ukrán nemzeti } \\
\text { mozgalmak elfojtása, oro- } \\
\text { szosítás, a nyugat- és } \\
\text { oroszbarát erők ellentéte, } \\
\text { háborús konfliktus a } 21 . \\
\text { század elején }\end{array}$ & \\
\hline
\end{tabular}




\section{Jegyzetek}

1 A Levada Központ 2018. áprilisi krími felmérésének eredményei: https://www. levada.ru/en/2018/04/17/crimea-2/ (Letöltés: 2018. július 9.).

2 Itt szükséges röviden utalnunk rá, hogy Turner később arra törekedett, hogy van Gennep eredeti „liminális” kifejezését továbbra is csak kis törzsi csoportok esetében alkalmazza, míg a modern világ hasonló jelenségeinek magyarázatához egy 1974-ben megjelent tanulmányában bevezette a „liminoid” kifejezést. Ezzel olyan élményekre utalt, amelyek a liminális élményekhez hasonló jellemvonásokkal rendelkeznek, ám egyrészt opcionálisak, másrészt nem egy személyes válság feloldását szolgálják. Míg a liminális a társadalom integráns része, addig a liminoid inkább elszakadás a társadalomtól, amely Turner (1974) értelmezésében egyfajta „játéknak” tekinthető. Véleménye szerint az ipari társadalmakban a liminális rítusok egyre ritkábbak (sőt, egyenesen eltűnőfélben vannak), azonban ezek helyét fokozatosan átveszik rájuk sok szempontból hasonlító - ám szekuláris - liminoid rítusok. E különbségtétel ellenére tanulmányunkban egységesen az eredeti „liminális”, „liminalitás” kifejezéseket használjuk. Ez utóbbira szolgál példaként Karl Jaspers német filozófus „tengelykor” fogalma (Jaspers 1949).

4 A liminalitás koncepcióját egész társadalmak esetében alkalmazó nagyobb, átfogó munkák közül lásd például Norton (1988), Szakolczai (2000, 2003), Wydra (2000) köteteit vagy Eisenstadt (1992) tanulmányát. Természetesen e szerzők mindegyike tisztában van azzal, hogy egyetlen társadalom sem statikus, így maga a liminalitás sem tekinthető a „változás”, az „(át)alakulás”, az „átmenet”, a „transzformáció” puszta szinonimájának.

5 Tanulmányunkban az ún. transzkaukázusi államok (Örményország, Grúzia és Azerbajdzsán) lakóit nem tekintjük kaukázusi népeknek.

6 A Csecsen-Ingus ASZSZK létrehozásával a két népcsoport a korabeli statisztikákban együtt szerepel. Becslések (Burds 2007) alapján a terület népességének létszáma kb. 500000 fó lehetett (amelyből a csecsenek létszáma 400000 fö feletti), tehát a szovjet hatóságok beszámolóiból részletesen ismert deportálási folyamat valóban a teljes népességet érintette.

7 Többségük Szibériába került, kb. 50-60 000-en kerültek a GULAG javító-nevelő munkatáboraiba (Heller, Nyekrics 1996). A német haderő bevonulása előtt az emberveszteségek növekedtek azáltal, hogy a területet elhagyó szovjetek módszeresen likvidálták a politikai foglyaikat.

8 A liminalitás időben való kiterjesztését Turner (1969) a marginális közösségekhez köti: ilyennek tekinti pl. a ferences rendi szerzeteseket, akiket Szent Ferenc az „antistruktúrában”, az állandósult liminalitás állapotában próbál tartani. Míg Turner a permanens liminalitást kis közösségekhez köti, addig mások egész társadalmakra, nagy történelmi korszakokra is alkalmazhatónak tartják (Szakolczai 2009, 2014; Thomassen 2015), Martínez (2013) szerint pedig maga a többszörös értelemben is periferikus Oroszország jellemezhető folyamatosan jelen lévő liminalitással. Véleményünk szerint az egész társadalmakra, illetve birodalmakra alkalmazott „permanens liminalitás” fogalma az eredeti elmélet olyan mértékű kiterjesztése, amely kérdésessé és vitathatóvá teszi a liminalitás jellemzőinek megragadhatóságát, ezért azt sokkal inkább a metaforikus megközelítések közé soroljuk.

9 Ennek egyik ékes példája az 1954-es év, amikor az ukrán állam létének 300. évfordulóját ünnepelték. Ez valójában annak a szerződéskötésnek az évfordulója volt, amely kimondta a korábban a lengyel-litván államhoz tartozó kozákok által ellenőrzött területek Oroszországhoz csatolását. E jeles alkalom ünneplése közepette Hruscsov, aki korábban az Ukrán SZSZK-ban töltött be főtitkári posztot, Ukrajnának ajándékozta a Krím félszigetet.

10 Tanulmányunkban az ukrán államban élők ukrán és orosz nemzeti identitása mentén megfogalmazható kettősségre fókuszálunk, amely döntő jelentőségű az egész ukrán nemzet (mint elképzelt közösség) liminalitásának fenntartásában, ezért eltekintünk attól az identitásban jelentkező átmenetiségtől, amely a helyi közösségekben sokkal inkább tetten érhető. 


\section{Köszönetnyilvánítás}

A tanulmány a K 124291 számú, A poszt-szovjet után (?): A változó kelet-európai pufferzóna társadalmi folyamatainak földrajzi vizsgálata című projekt keretében, a Nemzeti Kutatási, Fejlesztési és Innovációs Hivatal (NKFIH) támogatásával készült. Berki Márton esetében a kutatást az ELTE Felsőoktatási Intézményi Kiválósági Program (1783-3/2018/FEKUTSRAT) keretében az Emberi Erőforrások Minisztériuma is támogatta.

\section{Irodalom}

Agnew, J. (1994): The territorial trap: The geographical assumptions of international relations theory. Review of International Political Economy, 1., 53-80. http://doi.org/frmxf2

Aydıngün, I., Aydıngün, A. (2007): Crimean Tatars return home: Identity and cultural revival. Journal of Ethnic and Migration Studies, 1., 113-128. http://doi.org/chv8sw

Anderson, B. (2006): Elképzelt közösségek: Gondolatok a nacionalizmus eredetéról és elterjedéséról. L'Harmattan, Budapest

Black, J. L. (1999): Russia and NATO expansion eastward: Red-lining the Baltic states. International Journal, 2., 249-266. http://doi.org/cwtt

Blandy, C. (1996): Cutting the Chechen knot. The World Today, 6., 147-149.

Boeck, B. J. (2008): When Peter I was forced to settle for less: Coerced labor and resistance in a failed Russian colony (1695-1711). The Journal of Modern History, 3., 485-514. http://doi.org/bp3dz5

Bottlik Zs. (2016): Az etnicitás kérdése a köztes-európai térségben. In: Bottlik Zs. (szerk.): Etnikai földrajzi kutatások a Kárpát-Balkán régióban. ELTE, Budapest, 17-25.

Bottlik Zs., Karácsonyi D. (2018): Ukrajna kétarcúságának etnikai földrajzi háttere. In: Bottlik Zs. (szerk.): Etnikai földrajzi kutatások Köztes-Európában. ELTE, Budapest, 43-61.

Bruce, S. (2000): The supply-side model of religion: The Nordic and Baltic states. Journal for the Scientific Study of Religion, 1., 32-46. http://doi.org/bz4g9j

Burds, J. (2007): The Soviet war against 'fifth columnists': The case of Chechnya, 1942-4. Journal of Contemporary History, 2., 267-314. http://doi.org/cqjdjv

Cresswell, T. (1996): In place/out of place: Geography, ideology, and transgression. University of Minnesota Press, Minneapolis

Czepczyński, M. (2008): Cultural landscapes of post-socialist cities: Representation of powers and needs. Ashgate, Aldershot

Czepczyński, M. (2010): Interpreting post-socialist icons: From pride and hate towards disappearance and/or assimilation. Human Geographies - Journal of Studies and Research in Human Geography, 1., 67-78.

Dam, C. (2011): How to feud and rebel: 2. Histories, cultures and grievances of the Chechens and Albanians. Iran \& the Caucasus, 1-2., 235-273.

Eisenstadt, S. (1992): The order-maintaining and order-transforming dimensions of culture. In: Münch, R., Smelser, N. (eds.): Theory of culture. University of California Press, Berkeley, 64-87.

Elson, A. (1997): Baltic state membership in the European Union: Developing a common asylum and immigration policy. Indiana Journal of Global Legal Studies, 1., 317-340.

Fisher, A. (1967): Şahin Girey, the reformer khan, and the Russian annexation of the Crimea. Jahrbücher für Geschichte Osteuropas, 3., 341-364.

Galtung, J. (1969): Violence, peace and peace research. Journal of Peace Research, 3., 167-191. http://doi.org/cv8mgh

Gee, G. (1995): Geography, nationality, and religion in Ukraine: A research note. Journal for the Scientific Study of Religion, 3., 383-390. http://doi.org/bzqm5h

Gould, R. (2014): The lonely hero and Chechen modernity: Interpreting the story of Gekha the Abrek. Journal of Folklore Research, 2., 199-222. http://doi.org/cwtv 
Heller, M. (1996): Az Orosz Birodalom története. Osiris, Budapest

Heller, M., Nyekrics, A. (1996): A Szovjetunió története. Osiris, Budapest

Horvath, A., Thomassen B., Wydra H. (eds.) (2015): Breaking boundaries: Varieties of liminality. Berghahn Books, Oxford http://doi.org/cwtw

Illés T. (2018): Egy pufferzóna etnikai földrajza: A Budzsák. In: Bottlik Zs. (szerk.): Etnikai földrajzi kutatások Köztes-Európában. ELTE, Budapest, 145-153.

Izhak, O. (2016): The threats and challenges of a multipolar world: A Ukraine crisis case study. Connections, 1., 32-44. http://doi.org/cwtx

Jaspers, K. (1949): Vom Ursprung und Ziel der Geschichte. Piper, München

Katchanovski, I. (2005): Small nations but great differences: Political orientations and cultures of the Crimean Tatars and the Gagauz. Europe-Asia Studies, 6., 877-894. http://doi.org/dkxp9r

Katchanovski, I. (2010): The politics of Soviet and Nazi genocides in Orange Ukraine. Europe-Asia Studies, 6., 973-997. http://doi.org/cr4fqp

Kerr, D. (1995): The new Eurasianism: The rise of geopolitics in Russia's foreign policy. Europe-Asia Studies, 6., 977-988. http://doi.org/fm9m8c

Kirimli, H. (2008): Emigrations from the Crimea to the Ottoman Empire during the Crimean war. Middle Eastern Studies, 5., 751-773. http://doi.org/bqk3ft

Korotich, V. (1992): The Ukraine rising. Foreign Policy, 85., 73-82.

Kőszegi M. (2018): A hatalom hálójában: Kis nemzetek és etnikumok a Fekete-tenger partján. In: Bottlik Zs. (szerk.): Etnikai földrajzi kutatások Köztes-Európában. ELTE, Budapest, 199-214.

Mälksoo, M. (2010): The politics of becoming European: A study of Polish and Baltic post-cold war security images. Routledge, New York

Martínez, F. (2013): On the peripheral character of Russia. e-cadernos CES, 19., 54-84. http://doi.org/cwtz

Mearsheimer, J. (2014): Why the Ukraine crisis is the West's fault: The liberal delusions that provoked Putin. Foreign Affairs, 5., 77-84, 85-89.

Medvedev, S. (1997): A general theory of Russian space: A gay science and a rigorous science. Alternatives: Global, Local, Political, 4., 523-553. http://doi.org/cwt2

Nichols, J. (2004): The origin of the Chechen and Ingush: A study in alpine linguistic and ethnic geography. Anthropological Linguistics, 2., 129-155.

Norton, A. (1988): Reflections on political identity. Johns Hopkins University Press, Baltimore

O'Loughlin, J., Ó Tuathail, G., Kolossov, V. (2006): The geopolitical orientations of ordinary Russians: A public opinion analysis. Eurasian Geography and Economics, 2., 129-152. http://doi.org/bm665d

Ortayli, I. (1991): Reports and considerations of Ismail Bey Gasprinskii in ‘Tercüman' on Central Asia. Cahiers du Monde russe et soviétique, 1., 43-46. http://doi.org/cnx8bx

Paasi, A. (1997): Territories, boundaries and consciousness: The changing geographies of the Finnish-Russian border. John Wiley \& Sons, Chichester

Pain, E. (2016): The imperial syndrome and its influence on Russian nationalism. In: Kolstø, P., Blakkisrud, H. (eds.): The new Russian nationalism. Edinburgh University Press, Edinburgh, 46-74. http://doi.org/cwt3

Piip, A. (1933): The Baltic states as a regional unity. The Annals of the American Academy of Political and Social Science, 1., 171-177. http://doi.org/cpp9nq

Ponarin, E. (2000): The prospects of assimilation of the Russophone populations in Estonia and Ukraine: A reaction to David Laitin's research. Europe-Asia Studies, 8., 1535-1541. http://doi.org/c2pc3b

Roberts, L. (2018): Spatial anthropology: Excursions in liminal space. Rowman \& Littlefield, London

Saburova, I. (1955): The Soviet occupation of the Baltic states. The Russian Review, 1., 36-49. http://doi.org/bjbqn2

Senn, A. (1958): The sovietization of the Baltic states. The Annals of the American Academy of Political and Social Science, 1., 123-129. http://doi.org/dnkn7w

Souleimanov, E., Dytrich, O. (2008): The internationalisation of the Russian-Chechen conflict: Myths and reality. Europe-Asia Studies, 7., 1199-1222. http://doi.org/bsdz9j

Szakolczai, Á. (2000): Reflexive historical sociology. Routledge, London 
Szakolczai, Á. (2003): The genesis of modernity. Routledge, London

Szakolczai, Á. (2009): Liminality and experience: Structuring transitory situations and transformative events. International Political Anthropology, 1., 141-172.

Szakolczai, Á. (2014): Living permanent liminality: The recent transition experience in Ireland. Irish Journal of Sociology, 1., 28-50. http://doi.org/cwt4

Thomassen, B. (2006): Liminality. In: Harrington, A., Marshall, B., Müller, H-P. (eds.): Routledge encyclopedia of social theory. Routledge, London, 322-323.

Thomassen, B. (2009): The uses and meanings of liminality. International Political Anthropology, 1., $5-27$.

Thomassen, B. (2015): Thinking with liminality: To the boundaries of an anthropological concept. In: Horvath, A., Thomassen B., Wydra H. (eds.): Breaking boundaries: Varieties of liminality. Berghahn Books, Oxford, 39-58. http://doi.org/cwt5

Turner, V. (1967): The forest of symbols: Aspects of the Ndembu ritual. Cornell University Press, Ithaca

Turner, V. (1969): The ritual process: Structure and anti-structure. Routledge, Kegan Paul, London

Turner, V. (1974): Liminal to liminoid in play, flow and ritual: An essay in comparative symbology. Rice University Studies, 3., 53-92.

Tuvikene, T. (2016): Strategies for comparative urbanism: Post-socialism as a de-territorialized concept. International Journal of Urban and Regional Research, 1., 132-146. http://doi.org/f8wj3b

van Gennep, A. (1909): Les rites de passage. Noury, Paris

Werth, N. (2006): The 'Chechen problem': Handling an awkward legacy, 1918-1958. Contemporary European History, 3., 347-366. http://doi.org/d5bwh5

Williams, B. (2000a): Hijra and forced migration from nineteenth-century Russia to the Ottoman Empire: A critical analysis of the Great Crimean Tatar emigration of 1860-1861. Cahiers $d u$ Monde russe, 1., 79-108. http://doi.org/cwt6

Williams, B. (2000b): Commemorating 'the deportation' in post-Soviet Chechnya: The role of memorialization and collective memory in the 1994-1996 and 1999-2000 Russo-Chechen wars. History and Memory, 1., 101-134.

Williams, B. (2001): The ethnogenesis of the Crimean Tatars: An historical reinterpretation. Journal of the Royal Asiatic Society, 3., 329-348. http://doi.org/fj94c9

Williams, B. (2002): Hidden ethnocide in the Soviet Muslim borderlands: The ethnic cleansing of the Crimean Tatars. Journal of Genocide Research, 3., 357-373. http://doi.org/dmv42g

Wydra, H. (2000): Continuities in Poland's permanent transition. Macmillan, Basingstoke http://doi.org/cwd9hk Zaloznaya, M., Gerber, T. (2012): Migration as social movement: Voluntary group migration and the Crimean Tatar repatriation. Population and Development Review, 2., 259-284. http://doi.org/cwt7 